\title{
Mansfield Amendment Cut Down
}

by our Washington Correspondent

The law requiring that all the research sponsored by the Department of Defense should be of direct military relevance has become a dead letter, although it will probably continue to exert its influence from beyond the grave. The law, known as the Mansfield amendment to last year's military procurement authorization act, was re-included in the bill for the present financial year by the Senate but not by the House of Representatives. In negotiations between the two chambers reported last week, the delegates from the Senate were forced to yield on the Mansfield amendment in return for House concessions on other points in the bill, notably the Senate's stand on limiting the Safeguard anti-ballistic missile system to defending only missile sites. The importance of the amendment is that it knocked away the most conspicuous pillar of American science policy, the practice whereby the bulk of Federal support of science is channelled through the large mission orientcd agencies such as the Department of Defense, instead of through the relatively puny National Science Foundation.

The price paid by the Senate for its position on the ABM was to allow the House to sabotage the Mansfield amendment beyond repair and to adulterate a corollary provision that the budget of the National Science Foundation should be increased. The crucial wording in the Mansfield amendment, that no research project should be supported by the Department of Defense "unless such project or study has a direct and apparent relationship to a specific military function or operation", has been replaced by the jejune stipulation "unless such project or study has, in the opinion of the Secretary of Defense, a potential relationship to a military function or operation".

This language was arrived at after rejection of a compromise Senate proposal that would have distinguished between applied and basic research, using a test of strict relevancy for the former but asking only for "clear potential relevancy" on the latter. But the House conferees were adamant that no restriction should be placed on the Pentagon's freedom to conduct whatever basic research it wanted, and insisted that the concept of military relevancy "should not be used as the determining factor in the support of basic research efforts of contractors, universities, or nonprofit institutions".

The House conferees also took exception to the Senate's indication that the budget of the National Science Foundation for the financial year starting in July 1971 should be increased by a fifth. The reason given was that "this matter had not been a subject of House Committee hearings and therefore was not a matter on which the House members were prepared to act". The House Subcommittee on Science, Research and Development has held extensive hearings on the general issues involved, though not on the Senate proposal specifically, but these do not seem to count for much with the House Armed Services Committee, whose conferees were in charge of the negotiations. As a result the Senate's call for a stronger role to be played by the National Science Foundation has come out much watered down.

The Senate also had to give way on its proposal for an Interagency Council on Domestic Applications of Defense Research, which would have sought to convert the resources of defence industries, now underutilized because of budget cutbacks, to the solution of domestic problems. The House conferees argued that this type of coordination was the job of the Federal Council for Science and Technology but in any case they were unwilling to accept the Senate view of the matter since the House Armed Services Committee had not held hearings on it.

In the debate on the conferees' report Senator Mike Mansfield made no secret of his disappointment at the concessions that had been made. The alteration to his amendment, he said, is worse than eliminating it altogether since it "affirmatively states that the Department of Defense will solely determine what research is beneficial to it. This language, in $\mathrm{my}$ opinion, is a legislative act of abdication to the Secretary of Defense..." The Senator still hoped for "an alignment not only in what is necessary for military and scientific development ... but also in that which can be allocated to the National Science Foundation and other civilian agencies engaged in basic research...." Mr Mansfield gave notice that his fight to achieve this reallocation was far from ended, it had just begun again.

The virtual repeal of the Mansfield amendment will give the Pentagon less freedom to continue its support of the full spcetrum of basic research-its "backdoor National Science Foundation", as Senator Mansfield has termed it - than in the days when Congress happily disbursed whatever the generals said was needed. But although in the short term the demise of the amendment may allow more funds for basic research. the long term prospects, even if the amendment is not resurrected next year, are less certain. Mr Mendel Rivers, the chairman of the House Armed Services Committee, has gelded the Mansfield amendment not bccause he thinks it may harm science but because it does no obvious good to the Pentagon. In Senator Mansfield's mind too, the inought of cutting the Pentagon down to size may loom larger than that of building up the National Science Foundation, but at least the Scnator has laid out a logical and constructive design of how he envisages science should be supported. 'The whole question of science funding has now been thrown back into the political arena where it stands to be decided not on its own merits but as part of the tussle between the friends and foes of the Pentagon. To this extent the Senate's sacrifice of the amendment is a doubtful benefice. 